\title{
Rafal Szymanowski
}

Uniwersytet im. Adama Mickiewicza w Poznaniu

\section{Przestrzeń możliwości według Haralda Welzera}

\author{
Selbst Denken. Eine Anleitung zum Widerstand \\ Harald Welzer \\ S. Fischer Verlag, Frankfurt am Main 2013, \\ Ss. 336 .
}

$\mathrm{P}$ OŚRÓD LICZNYCH GRUNTOWNYCH PRZEOBRAŻEŃ, które zaszły w ciągu ostatnich kilku dekad w liberalnych demokracjach bogatego Zachodu, jest również zmiana społecznie dominującej wizji przyszłości. Jeszcze nie tak dawno temu, na przełomie lat 60. i 70. XX wieku dla przeciętnego mieszkańca Republiki Federalnej Niemiec, przyszłość była obietnicą. Ludzie żywili nadzieję, iż to, co wkrótce nadejdzie, będzie lepsze od tego, co już istniało. Oczekiwania te miały zupełnie racjonalne podstawy. Pokolenie powojennego baby-boomu radziło sobie w świecie lepiej niż wszystkie generacje wcześniej, trwał okres najbardziej dynamicznego wzrostu gospodarczego w historii ludzkości. Polityka gospodarcza była egalitarystyczna. W Stanach Zjednoczonych aż do czasów Lyndona Bainesa Johnsona rządzili liberalni demokratyczni prezydenci, albo niewiele różniący się od nich, pogodzeni z dziedzictwem Nowego Ładu Republikanie, tacy jak Dwight Eisenhower ${ }^{1}$. W Europie Zachodniej trwał w najlepsze socjaldemokratyczno-chadecki konsensus, który roztoczył parasol ochronny nad powojennym państwem dobrobytu². Wcześniej niewyobrażalne działo się na oczach wszystkich mieszkańców planety - gdy w 1969 roku pierwszy człowiek postawił nogę na księżycu, wszystko wydawało się możliwe i osiągalne. Kilka dekad później, w środku drugiej dekady trzeciego millenium próżno szukać śladów tamtego nastroju. Dziś, w rzeczywistości trapionej wszelkimi możliwymi kryzysami, od finansowego, poprzez demograficzny, surowcowy i ekologiczny, aż do kryzysu przywództwa, przy-

${ }^{1}$ P. Krugman, The Conscience of a Liberal. Reclaiming America from the Right, London 2007, s. 10.

${ }^{2}$ T. Judt, Powojnie. Historia Europy od roku 1945, Poznań 2013, s. 426-46o. 
szłość zamiast być obietnicą, stanowi raczej zagrożenie. Niemal każdy jej wariant, który racjonalny umysł potrafi sobie wyobrazić, może być tylko gorszy od teraźniejszości.

Właśnie od charakterystyki tej zastanawiającej zmiany naszej wizji przyszłości zaczyna swoją najnowszą pracę niemiecki psycholog społeczny Harald Welzer. I choć książka rozpoczyna się opisem określonego społecznie podzielanego wyobrażenia $(\mathrm{H}$. Welzer pozostaje tu blisko przedmiotu poznania dyscypliny, z której się wywodzi) to Selbst Denken. Eine Anleitung zum Widerstand (Myśl za siebie. Instrukcja oporu) jest tak naprawdę głęboko politycznym manifestem³ ${ }^{3}$. Badacza, który swoje pierwsze prace poświęcał zagadnieniom psychologii ludobójstwa, zbrodniom wojennym żołnierzy Wehrmachtu oraz pamięci o narodowym socjalizmie w Niemczech, od kilku lat zajmuje inna problematyka. Wspólnym mianownikiem ostatnich prac H. Welzera jest opis zachodniego ekspansywnego modelu rozwoju i jego radykalna krytyka. Psycholog twierdzi, iż nie tylko dotarł on do kresu swoich możliwości, ale również przyczynił się do wybuchu praktycznie wszystkich współczesnych kryzysów. W najnowszej książce H. Welzer kontynuuje tematy poruszone już w Końcu świata, jaki znaliśmy i Wojnach klimatycznych, zwracając uwagę na konieczność redefinicji założeń i środków polityki rozwoju prowadzonej przez zachodnie liberalne demokracje.

Inspirująca i prowokująca do dalszej dyskusji jest w pracy $\mathrm{H}$. Welzera obserwacja, iż ekspansywny model rozwoju, ze zróżnicowaną intensywnością wcielany w życie w zdecydowanej większości państw zachodnich, pomyślany był jako model partykularny. Badacz nie odmawia mu wielu zasług - to dzięki niemu obywatele bogatego Zachodu korzystają z dobrodziejstw nie tylko liberalnej demokracji i wolnorynkowej gospodarki, lecz także wolności słowa, praw człowieka, systemów opieki zdrowia i edukacji. Jednak warunkiem sine qua non funkcjonowania owego modelu była eksploatacja, w czasach kolonial-

${ }^{3}$ H. Welzer, Selbst Denken. Eine Anleitung zum Widerstand, Frankfurt am Main 2013. Warto zauważyć, iż już w tytule badacz nawiązuje do kantowskiego programu oświecenia, który postulował odwagę posługiwania się rozumem. Zdaniem H. Welzera od czasów Immanuela Kanta istota tego apelu nie uległa zmianie. Dziś także człowiek musi odważyć się na „wyjście ze stanu zawinionej niedojrzałości”. Zmieniły się natomiast mechanizmy opresji i źródła skrępowania jednostkowego intelektu. Dawniej ludzi otępiały religijne zabobony, prymitywne wierzenia i rady teologów, dzisiaj robią to wiary naszych czasów: rentowność, opłacalność, maksymalizacja zysku, a przede wszystkim to, co H. Welzer nazywa „religią wzrostu gospodarczego”. 
nych za pomocą przemocy i środków przymusu bezpośredniego, później w sposób bardziej wysublimowany, jakiegoś „zewnątrz”. Psycholog podkreśla, iż nikt nie sądził, iż ten model powinien upowszechnić się w skali światowej. Problemy współczesnego świata wynikają więc stąd, iż zglobalizował się model partykularny, opierający się na eksploatacji tego, co znajdowało się na zewnątrz wobec niego. Zglobalizowany świat ${ }^{4}$ nie ma jednak żadnego „zewnątrz”, przynajmniej w sensie przestrzennym. Jednym jedynym „zewnątrz”, które w XXI wieku wciąż pozostaje do dyspozycji jest zatem czas, a konkretnie przyszłość. H. Welzer powtarza tu myśl niemieckiego literaturoznawcy Albrechta Koschorke, który sformułował ją jako pierwszy w artykule o znamiennym tytule „Gra z przyszłością” („Spiel mit der Zukunft”)). Sposób rozwiązywania wszystkich współczesnych kryzysów polega zatem, według H. Welzera, na prostym przestawieniu się z eksploatowania przestrzeni (Die Ausbeutung des Raumes) na eksploatowanie przyszłości (Die Ausbeutung des Zukunft).

Wyrażona przez H. Welzera obserwacja, choć z pewnością może budzić wiele zastrzeżeń i kontrowersji, uwrażliwia jednak autora na najbardziej palące problemy współczesnego świata, pozwalając mu dostrzec m.in. całkiem realną niesprawiedliwość międzygeneracyjną. Zauważa on, iż postępujące od czasów buntu studenckiego '68 „uwolnienie jednostki” spod władzy wspólnoty: procesy indywidualizacji i liberalizacji obyczajowej połączone z rewolucją neoliberalną w ekonomii osłabiły solidarność społeczną i naderwały więzy międzypokoleniowe. Dawniej poczucie pewnej ciągłości i tradycja powodowały, iż ludzie czuli się odpowiedzialni za świat, który przekazywali pokoleniu swoich dzieci. Współczesna pedagogika społeczna, jak podkreśla wielu specjalistów, wychowuje ludzi mogących liczyć tylko na siebie. Dziś każdy z osobna zmuszony jest wypracować własną, by posłużyć się terminem Anthony'ego Giddensa, „politykę życia”: indywidualną strategię przetrwania i poradzenia sobie w nieprzyjaznej i nierozpoznanej

${ }^{4}$ Terminu „zglobalizowany świat” (Die globalisierte Welt) używam w niniejszym tekście za H. Welzerem, który sam posługuje się nim wielokrotnie na kartach swojej pracy. Warto jednak pamiętać, iż z punktu widzenia poprawności językowej stanowi on tautologię. Jak przypomina ekonomista Grzegorz W. Kołodko „globalizacja świata” znaczy tyle co „uświatowienie globu”. „Zglobalizowany świat” jest więc trochę jak „masło maślane” czy „kwiecisty kwiat”. Świat jest z definicji „światowy”, a glob jest także z definicji „globalny”. Zob. G. W. Kołodko, Dokąd zmierza świat? Ekonomia polityczna przysztości, Warszawa 2013, s. 94.

${ }^{5}$ A. Koschorke, Spiel mit der Zukunft, http://www.exc16.de/cms/fiktion-zukunft. html, 29.08.2013 r. 
rzeczywistości. Troska o to, jak będzie wyglądał świat za kilkadziesiąt lat, pozostaje poza horyzontem bieżących zmartwień większości ludzi. W badaniach Boston Consulting Group tylko 13\% ankietowanych deklaruje, iż wierzy, że ich dzieciom będzie się lepiej wiodło niż im samym. H. Welzer zauważa, iż obywatele bogatych i wysokorozwiniętych państw zachodnich nie tylko żyją na koszt przyszłych pokoleń, lecz także, paradoksalnie, przekazują w spadku swoim dzieciom i wnukom - dzisiejszym nastolatkom - świat dużo mniejszych szans, dramatycznie skurczoną przestrzeń możliwości ${ }^{6}$.

H. Welzer, który oprócz swojej działalności naukowej jest też jednym z najbardziej aktywnych uczestników debaty publicznej w Niemczech, stał się w ostatnich latach jedną z twarzy coraz popularniejszego ruchu na rzecz wyhamowania dynamiki wzrostu gospodarczego. Nie przypadkiem w Berlinie na promocji książki How much is enough? Money and the Good Life interlokutorem jej autora, znanego brytyjskiego ekonomisty Roberta Skidelsky'ego był właśnie H. Welzer. Ten nowy ruch społeczny przypomina, iż w świecie ograniczonym w zasoby nie ma miejsca na nieograniczony wzrost. Eksterioryzacja kosztów i życie na kredyt, dwie najbardziej efektywne dźwignie sukcesu gospodarczego od lat 80 . XX wieku, nie nadają się do uniwersalizacji i uwiecznienia, ze swej natury mogą być tylko miejscowe i tymczasowe7 ${ }^{7}$ W nowej książce $\mathrm{H}$. Welzera kpiny z apostołów religii wzrostu przeplatają się z krytyką polityki gabinetu Angeli Merkel. Badacz przypomina umowę między CDU/CSU i FDP, której podpisaniem w 2009 roku uroczyście zainaugurowała rządy nowa czarno-żółta koalicja. Dokument ów nosił tytuł „Wachstum. Bildung. Zusammenhalt“, czyli „Wzrost. Edukacja. Spójność”. Psycholog stwierdza, iż nawet z punktu widzenia teorii ekonomii wzrost gospodarczy nie jest niczym więcej niż środkiem umożliwiającym osiągnięcie społecznie pożądanych celów

\footnotetext{
${ }^{6}$ Warto zauważyć, iż niemiecki psycholog nie jest pierwszym badaczem, który w ostatnim czasie publicznie sformułował ciężkie zarzuty pod adresem własnego pokolenia. David Willets, konserwatywny minister odpowiadający w rządzie Davida Camerona za naukę i uniwersytety, wyraził radykalną opinię, iż pokolenie wyżu demograficznego, dzierżące stery władzy w Wielkiej Brytanii, prowadzi politykę zgodną ze swoimi interesami, ignorując potrzeby młodego pokolenia. Willets pytał w swojej książce, czy to przypadek, że neoliberalizm łączy się z doktryną monetarną w zarządzaniu finansami publicznymi. Według niego to celowa strategia polityki antyinflacyjnej, która służy ochronie oszczędności tych, którzy już zdążyli je zgromadzić, a nie sprzyja tworzeniu miejsc pracy dla młodych. Zob. D. Willets, The Pinch. How the baby boomers took their children's future - and why they should give it back, London 2011.

7 Z. Bauman, Przedmowa, [w:] A. Leszczyński, Skok $w$ nowoczesność. Polityka wzrostu w krajach peryferyjnych 1943-1980, Warszawa 2013, s. 14.
} 
takich, jak powszechny dobrobyt, bezpieczeństwo socjalne, szczęście, zadowolenie z życia, czy właśnie wysoki poziom oświaty i spójności. Postawienie wzrostu obok edukacji i spójności jest więc pomyleniem pojęć, sprawia, iż wzrost urasta do rangi celu samego w sobie.

H. Welzer nie szczędzi cierpkich słów chadecko-liberalnej koalicji, a także zadowolonym z siebie, niemal bezkrytycznym wobec rządów Merkel niemieckim wyborcom. Jego krytyka wyrasta jednak z przekonania, iż obywatele mający przywilej życia w jednym z najbogatszych społeczeństw na Ziemi mają moralną powinność wzięcia odpowiedzialności za całą planetę. Warto pamiętać, iż w ramach debaty publicznej wywołanej współczesnym globalnym kryzysem ekonomicznym coraz powszechniejsze staje się przekonanie, iż trzeba wymyślić nowy paradygmat rozwoju. H. Welzer, adresując swoją książkę zwłaszcza do niemieckich czytelników, chce tym samym zapytać kto ma ten nowy model wymyślić, jak nie Niemcy - jedyne społeczeństwo, które wciąż w miarę suchą nogą przechodzi przez systemowy kryzys strefy euro. Czy jednak Niemcy mają ochotę takich pytań słuchać?

Przy okazji kolejnych pakietów pomocowych dla państw południa unii walutowej powracają w niemieckich mediach dyskusje dotyczące „unii transferowej” oraz granic możliwości finansowych „największego płatnika netto". Terminy te wdrukowują do głów Niemców przekonanie, iż nie tylko ponoszą cały ciężar finansowy unijnej kroplówki, ale wręcz stracili na wejściu w życie euro ${ }^{8}$. Zawirowania na kontynencie nie ułatwiają reform wewnętrznych. Niemiecki politolog Herfried Münkler wskazuje, iż w społeczeństwie występują określone cykle gotowości do zmian (Zyklen der Veränderungsbereitschaft ${ }^{9}$ ). Według niego Niemcy, doświadczeni dekadę temu całościową reformą państwa socjalnego i rynku pracy - Agendą 2010 Gerharda Schrödera, wraz z jej kluczowym elementem, osławionym Hartz IV nie są jesz-

\footnotetext{
${ }^{8}$ Jak słusznie zauważył brytyjski historyk Timothy Garton Ash w ciągu pierwszej dekady istnienia euro „Niemcy przyzwyczaili się do wspólnej waluty, jednak nigdy jej nie pokochali” - beznamiętnego uczucia, jakim obdarzyli euro w żaden sposób nie da się przyrównać do żarliwej miłości, jaką żywili wobec marki niemieckiej. Jest to paradoks, gdyż jak przypomina T. Garton Ash, to Niemcy są największymi wygranymi wspólnej waluty. To właśnie euro jako idealne uzupełnienie jednolitego rynku wewnętrznego umożliwiło tak dynamiczny rozkwit niemieckiej gospodarki opartej o model ekspansji eksportowej. Zob. T. Garton Ash, The New German Question, „The New York Review of Books", http://www.nybooks.com/articles/archives/2013/aug/15/new-germanquestion/?pagination=false, 01.09.2013 r.

${ }^{9}$ M. Feldenkirchen, C. Hoffmann, Die bequeme Republik, „Der Spiegel“ 2013, nr 32, s. 23 .
} 
cze gotowi na kolejne szokowe zmiany ${ }^{10}$. Wielu obserwatorów martwi jednak nie tyle brak gotowości Niemców do następnej politycznej rewolucji, lecz niechęć do niemal jakichkolwiek korekt. W debacie publicznej przed jesiennymi wyborami do Bundestagu coraz donośniej wybrzmiewają głosy określające dzisiejsze Niemcy mianem „wygodnej republiki”" oraz „drugiego Biedermeier"12. Zarzuca się wychowanej w bloku wschodnim Angeli Merkel, iż sprawując swoje rządy uksztaltowała dzisiejsze Niemcy na podobieństwo autorytarnej NRD z czasów jej młodości ${ }^{13}$. Pani kanclerz, twierdzą niektórzy, nie interesuje żywy i różnorodny dyskurs publiczny, nie widzi potrzeby wsłuchiwania się w głosy polemiczne wobec jej polityki, tłumi wszelki krytycyzm. Kultura polityczna nad Szprewą to kultura apatii; filozof Peter Sloterdijk mówi wręcz o „letargokratii”.

Warto jednak zauważyć, iż po raz pierwszy od bardzo dawna głosy krytyczne wobec polityki niemieckiej rozchodzą się nie tylko w samych Niemczech, lecz docierają także do innych państw w Europie. Tacy badacze jak Ulrich Beck, Wolfgang Streeck czy Heiner Flassbeck w ciągu ostatniego roku opublikowali szeroko dyskutowane, także i w Polsce, książki ${ }^{14}$. Każdy z tych tekstów poświęcony jest odrębnemu obszarowi problemowemu, lecz wszystkie z nich mają charakter silnie krytyczny wobec głównych założeń i kierunków polityki dotychczasowej koalicji. Warto zauważyć, iż samo Selbst denken przez kolejne miesiące nie schodziło z listy najchętniej w Niemczech kupowanych książek niebeletrystycznych, a na corocznym laboratorium idei dziennika „Die Tageszeitung” zorganizowanym w berlińskim „Haus der Kulturen der Welt” to właśnie dyskusja z H. Welzerem zgromadziła największą publiczność, frekwencyjnie przebijając nawet panel z udziałem urzędującego ministra środowiska Petera Altmaiera.

${ }^{10}$ Więcej o Agendzie 2010, Hartz IV i ich skutkach dla niemieckiej gospodarki i społeczeństwa zob. P. Buras, Muzułmanie i inni Niemcy. Republika berlińska wymyśla się na nowo, Warszawa 2011, s. 43-47; R. Woś, Mity o Agendzie 2010, http://forsal.pl/ artykuly/692846,wos_mity_o_agendzie_2010.html, 29.08.2013 r.

${ }^{11}$ M. Feldenkirchen, C. Hoffmann, Die bequeme, op. cit., s. 22.

${ }^{12}$ D. Kurbjuweit, Das zweite Biedermeier, „Der Spiegel“, http://www.spiegel.de/ spiegel/print/d-94865590.html, 29.08.2013.

${ }^{13}$ A. Krzemiński, Nadchodzi wiosna Europy?, „Przegląd Polityczny” 2012, nr 115/116, s. 38-45.

${ }^{14}$ U. Beck, Niemiecka Europa. Nowe krajobrazy władzy pod znakiem kryzysu, Warszawa 2013; H. Flassbeck, Zehn Mythen der Krise, Berlin 2013; W. Streeck, Gekaufte Zeit: Die vertagte Krise des demokratischen Kapitalismus, Berlin 2013. 
Kanclerz Angela Merkela - przy wszystkich zarzutach, które można formułować pod adresem jej polityki - udowodniła już nie jeden raz, iż jest politykiem bardzo elastycznym, przenikliwym i spostrzegawczym. Dzierżąc stery władzy przez kolejne cztery lata będzie musiała liczyć się z coraz ostrzejszą krytyką środowisk rozczarowanych jej polityką oraz, być może, pójść na pewne ustępstwa. Dysydenci „wygodnej republiki Merkel” będą zwierać swoje szeregi, wpływać na dyskurs publiczny oraz wywierać presję na koalicję, która uformuje się po jesiennych wyborach do Bundestagu. H. Welzer będzie jednym z najważniejszych reprezentantów tej grupy. Także dlatego warto znać jego prace.

\section{Nota O AUTORZE}

Rafał Szymanowski [rafal.szymanowski@amu.edu.pl] - doktorant w Zakładzie Gospodarki Międzynarodowej WNPiD UAM w Poznaniu. W kręgu jego zainteresowań badawczych znajdują się: ekonomia polityczna, procesy globalizacji, problematyka zmian cywilizacyjnych, współczesny światowy kryzys gospodarczy, nowe ruchy społeczne, a także przyszłość socjaldemokracji oraz państwa dobrobytu. 